\title{
Ecology of Phallotorynus pankalos (Cyprinodontiformes: Poeciliidae) in a first-order stream of the upper Paraná Basin
}

\author{
Yzel R. Súarez, João Paulo da Silva, Lilian P. Vasconcelos \\ and William Fernando Antonialli-Júnior
}

Some aspects of the population ecology of Phallotorynus pankalos in a first-order stream of the Iguatemi River Basin are described based on samples taken from March/2007 to February/2008. A total of 2680 individuals, including 948 males and 1732 females was collected. Adult females are larger than males; theirs mean fecundity was estimated as 6.5 embryos/female. There was a strong correlation between standard length and ovary weight, relative ovary weight, and number of embryos. The size of the first maturation of $50 \%$ of female population was estimated as $18.24 \mathrm{~mm}$ of standard lenght. High female mortality was observed after the first reproduction and sex ratio presents seasonal variation with higher female proportion in the winter.

Para descrever alguns aspectos da ecologia populacional de Phallotorynus pankalos em um riacho de primeira ordem da bacia do rio Iguatemi foram realizadas amostragens de março/2007 a fevereiro/2008. Um total de 2680 indivíduos, distribuídos em 948 machos e 1732 fêmeas, foi coletado. Fêmeas adultas foram maiores que os machos e sua fecundidade média foi estimada em 6,5 embriões/fêmea. Foi observada forte correlação entre o comprimento padrão e o peso dos ovários, peso relativo dos ovários e número de embriões. O tamanho da primeira maturação de $50 \%$ da população de fêmeas foi estimado em $18,24 \mathrm{~mm}$ de comprimento padrão. Observamos elevada mortalidade de fêmeas após a primeira reprodução e variação sazonal na proporção sexual, com maior proporção de fêmeas no inverno.

Key words: Fecundity, Iguatemi River Basin, Population ecology, Reproduction, Stream fish.

\section{Introduction}

Poeciliid fishes are widely distributed, with more than 300 species (Lucinda, 2003), occurring mainly in shallow waters being one of the dominant species in some regions, such as the Central America. Their flexibility in diet, life-history strategies and their ability to survive and reproduce under hypoxic conditions may have facilitated the exploitation of diverse habitats (Chapman, 1992).

Many studies have focused on evolutionary aspects of poeciliid species (Hendler, 1980; Hendler, 1983; Magurran et al., 1995; Langerhans, 2004). Some have treated morphological description and comparison of the sexes (Gusmão \& Pavanelli, 1996). Others have suggested that some species can be used to assess habitat integrity (Bozzetti \& Schulz, 2004; Cunico et al., 2006; Ferreira \& Casatti, 2006; Pinto et al., 2006; Vieira \& Shibatta, 2007), mainly Poecilia reticulata and Phalloceros caudimaculatus.

Population studies of poeciliid species are rare in Brazil. Among these are the studies of Machado et al. (2002) and Wolff et al. (2007) on the reproductive cycle and population biology of Phalloceros caudimaculatus (probably Phalloceros harpagos - see Lucinda, 2008) in upper Paraná Basin in São Paulo and Paraná States, respectively, and the study of Casatti et al. (2006) on the reproductive biology of Pamphorichthys hollandi in the upper Paraná Basin.

The genus Phallotorynus includes small poeciliid species, endemic to South America in drainages of the Paraíba do Sul, Paraná and Paraguay rivers. The species of this genus are poorly studied from the ecological viewpoint. However, taxonomic, systematic and descriptive studies of coloration, behavior, and morphology have been published. Phallotorynus pankalos was described based on few individuals sampled in Sossego stream in Iguatemi River Basin (Lucinda et al., 2005).

The present study aimed to gather initial population information for Phallotorynus pankalos, in a first-order stream of the Iguatemi River Basin, answering the following questions: (1) How much do the sexes differ in the weight-length relationship? (2) What is the size at first sexual maturation in females? (3) Is there a relationship between the female standard length and the sexual investment?

Universidade Estadual de Mato Grosso do Sul, Centro Integrado de Análise e Monitoramento Ambiental/Laboratório de Ecologia, Rodovia Dourados-Itahum km 12, 79804-970 Dourados, MS, Brazil. yzel@uems.br 


\section{Material and Methods}

\section{Study site}

The Iguatemi River Basin is strongly impacted by human actions, presenting high levels as deforestation and siltation in the major portion, principally by agricultural activities. The Iguatemi River is approximately $300 \mathrm{~km}$ long and located in the upper Paraná River basin in Mato Grosso do Sul State. There is a wide floodplain and marginal lakes in the lower parts of the basin. The middle stretch has a small floodplain and some marginal lakes with little connection with the river.

The predominant vegetation is the Cerrado, altering with semideciduous seasonal forest. The juncture of Iguatemi River with the Paraná River is located at an altitude of $226 \mathrm{~m}$, approximately $20 \mathrm{~km}$ from Sete Quedas Falls, an important biogeographical barrier now submerged by the Itaipu Reservoir.

Farming and ranching are the main economic activities. The Brazilian part of the area was logged intensively in the past, and timber extraction is still occurring in Paraguay. Together, deforestation and agriculture are causing siltation in much of the Iguatemi basin.

\section{Field and laboratory methods}

The fish samples were taken from March/2007 to February/2008 at three sites in the Iguatemi River Basin. However, we analyzed the fish from only one site (Sossego Stream) located at $23^{\circ} 38^{\prime} 41.4^{\prime \prime} \mathrm{S} 55^{\circ} 12^{\prime} 5.1^{\prime \prime} \mathrm{W}$, due to low catches at the other locations (Fig. 1). The samples were taken during daylight, with a rectangular $1.2 \times 0.8 \mathrm{~m}$ sieve, with $2 \mathrm{~mm}$ mesh size. Specimens were fixed in $10 \%$ formalin and preserved in $70 \%$ ethanol for biometric data measurement: length standard (LS), total weight (TW) and sex. Voucher individuals were deposited at the Coleção de Peixes of Universidade Estadual de Maringá (20 individuals -NUP 5839).

\section{Data analysis}

A Kolmogorov Smirnov test was used in order to compare length and weight distribution between sexes because the criteria for normality were not met, even after logarithmic transformation. This procedure was adopted for standard length classes of $2 \mathrm{~mm}$ and with relative abundance of males and females in each class. The length-weight relationships for each sex were obtained by non-linear regression.

For 35 females in final development stage of embryos, the ovary weight and relative ovary weight (ovary weight/total weight) were obtained. The number of embryos was obtained for 59 females and correlated (Pearson's r) with standard length, to assess the influence of female size on sexual investment. For 17 females, embryos length and weight were obtained and also correlated with female standard length.

The probability of female maturation was obtained using logistic regression, when the presence of eggs or embryos was used to define if the individuals are reproductive. Standard length was used as the explanatory variable, according to Roa et al. (1999). Then we estimated the size of first maturation of $50 \%$ of female population $\left(\mathrm{LS}_{50 \%}\right)$ and $100 \%$ of female population $\left(\mathrm{LS}_{100 \%}\right)$. The sex ratio (number of females per male) was calculated monthly and the chi-square $\left(\chi^{2}\right)$ test, with Yates correction was used to verify differences in sex ratio.

\section{Results}

A total of 2680 individuals of Phallotorynus pankalos were analyzed, including 948 males (35.4\%) and 1732 females (64.6\%). The maximum standard length of males was $22.3 \mathrm{~mm}$

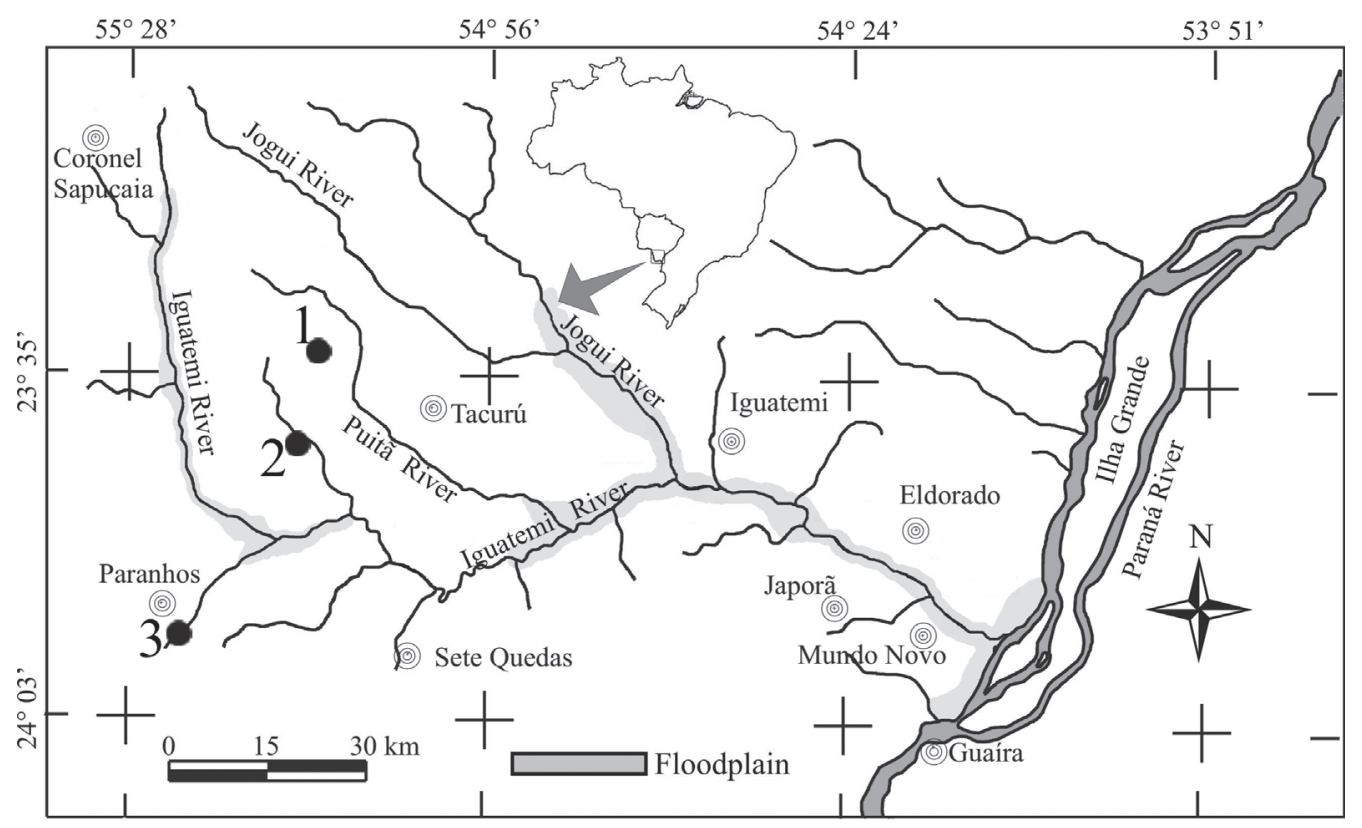

Fig. 1. Locations of the sampling sites with where Phallotorynus pankalos was recorded in the Iguatemi River Basin, upper Paraná River. 1- Sossego Stream; 2- Mirim Stream and 3- Piraí Stream. 
$($ median $=17.2 \mathrm{~mm})$ and for females was $37.2 \mathrm{~mm}($ median $=18$ $\mathrm{mm}$ ) (Fig. 2). The maximum total weight for males was $0.235 \mathrm{~g}$ (median $=0.092 \mathrm{~g})$ and for females was $1.298 \mathrm{~g}$ (median $=0.112$ g). We observed that the Total weight distribution differ between sexes $(\mathrm{P}=0.013)$, however the Standard length (LS) did not differ between sexes $(\mathrm{P}=0.097)$ (Fig. 2).

The length-weight relationship showed a larger increase of weight in females compared to males. Females showed an angular coefficient higher than 3, however males presented angular coefficient smaller than 3 (Table 1 and Fig. 3 ).

The mean number of embryos of reproductive females was estimated at 6.5, ranging from 2 to 16 embryos. The relative ovary weight ranged from $5.3 \%$ to $26.4 \%$. We found a significant influence of standard length of females on number of embryos $(\mathrm{r}=0.788 ; \mathrm{P}=0.000)$ and ovary weight $(\mathrm{r}=$ $0.829 ; \mathrm{P}=0.000)$. However, for relative ovary weight the correlation was marginally significant $(\mathrm{r}=0.394 ; \mathrm{P}=0.058)$, when with increasing size, investment in reproduction increased (Fig. 4). There was no significant correlation between the number of embryos and the mean total length of embryos $(\mathrm{r}=$ $0.102 ; \mathrm{P}=0.696$ ) and also between the number of embryos

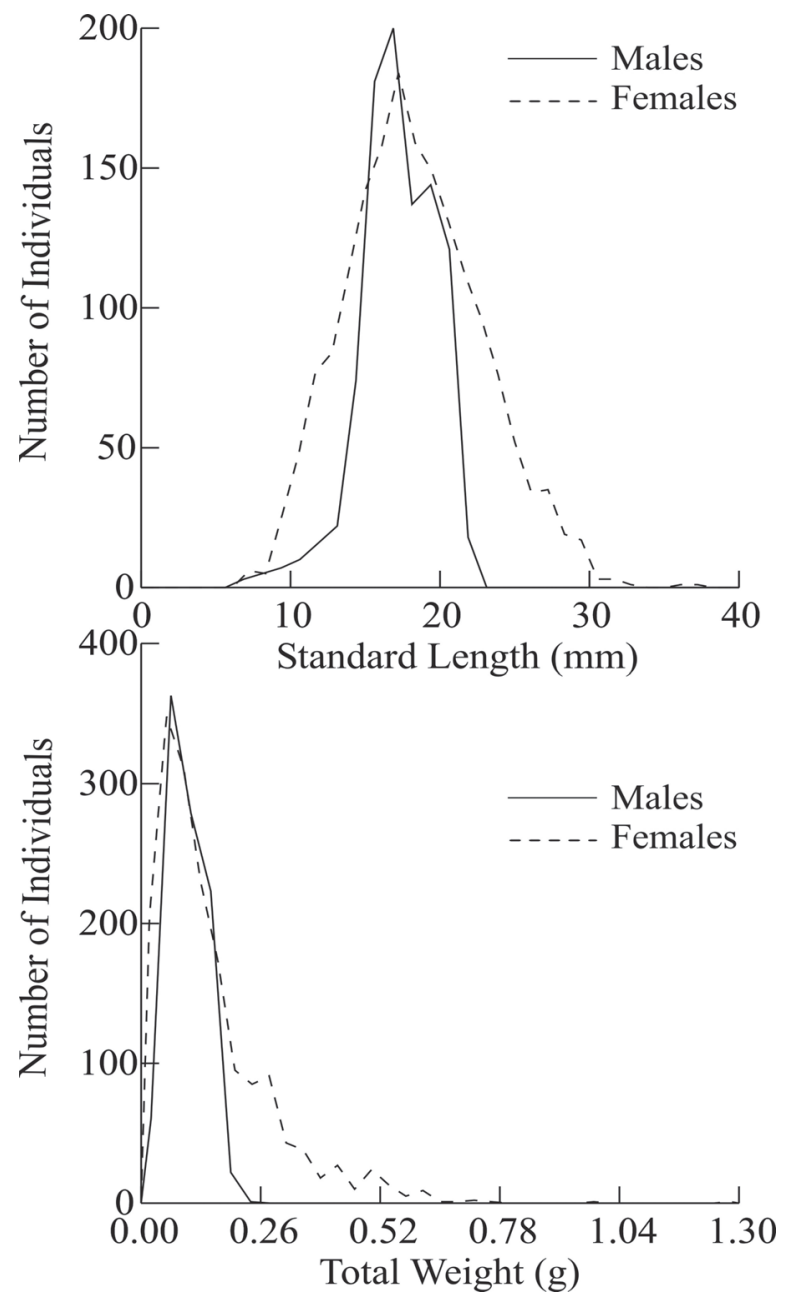

Fig. 2. Density plots of Standard Length $(\mathrm{mm})$ and Total Weight (g) for males and females of Phallotorynus pankalos in a first-order stream of the Iguatemi River Basin from March/ 2007 to February/2008. and the mean weight of embryos $(\mathrm{r}=-0.223 ; \mathrm{P}=0.389)$ i.e., the increase in number of embryos did not result in a decrease in embryo size (Fig. 5). We estimated that the size at first maturation of $50 \%$ of the female population was $18.2 \mathrm{~mm}$, and that of $100 \%$ of the female population was $25.6 \mathrm{~mm}$ (Fig. 6).

The mean total size of embryos in final development stage was estimated at $6.18 \mathrm{~mm}(\mathrm{sd}=0.55)$, weighting $0.006 \mathrm{~g}(\mathrm{sd}=$ 0.001). Embryo weight was significantly correlated with embryo size $(\mathrm{r}=0.593 ; \mathrm{P}=0.012$ ) (Fig. 7). However, no correlations were observed between female standard length and embryo size $(r=0.287 ; \mathrm{P}=0.265)$ and weight $(\mathrm{r}=-0.142 ; \mathrm{P}$ $=0.588$ ) (Fig. 8). The size of embryos represented approximately $28.4 \%$ of female standard length

The sex ratio was 1.82 females per male during the whole sampling period, and it varied seasonally $\left(\chi^{2}=175.67 ; \mathrm{P}<\right.$ 0.000 ) with higher values during winter, with 5.64 females by males in July (Fig. 9). Using the length frequency of females, we calculated that only $47.8 \%$ of females reached a size above $\mathrm{LS}_{50 \%}$, and only $6.4 \%$ of females reached a size above $\mathrm{LS}_{100 \%}$, suggesting high mortality after the first reproduction. In the laboratory, we observed that after reproducing, females had
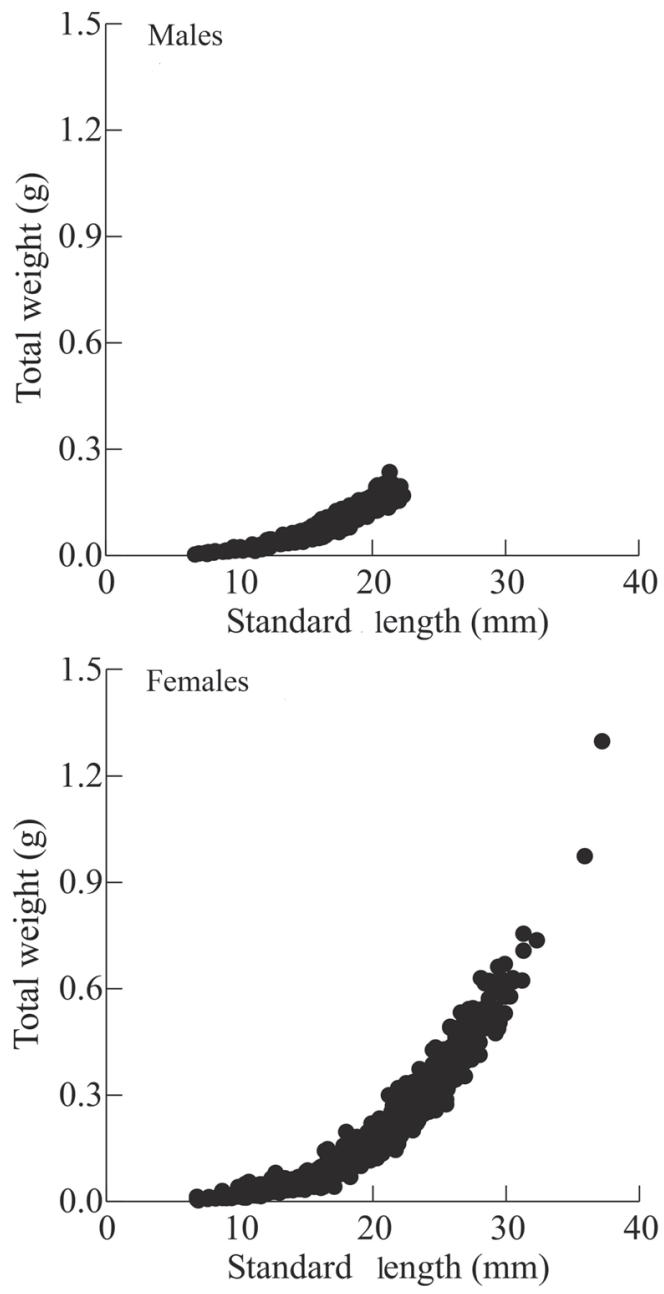

Fig. 3. Length-weight relationships for males and females of Phallotorynus pankalos in a first-order stream of the Iguatemi River Basin from March/2007 to February/2008. 
Table 1. Non-linear regression of length-weight relationships for Phallotorynus pankalos in a first-order stream of the Iguatemi River Basin. Estimated parameters and confidence interval.

\begin{tabular}{cccc}
\hline Sexes & Constant a & Angular coefficient $\mathrm{b}$ & $\mathrm{r}^{2}$ \\
\hline \multirow{2}{*}{ Males } & $2.27 \times 10^{-5}$ & 2.93 & \multirow{2}{*}{0.923} \\
& $\left(1.85 \times 10^{-6}\right.$ to $\left.2.68 \times 10^{-5}\right)$ & $(2.86-2.99)$ & \\
Females & $8.52 \times 10^{-6}$ & 3.29 & \multirow{2}{*}{0.967} \\
& $\left(7.72 \times 10^{-6}\right.$ to $\left.9.32 \times 10^{-6}\right)$ & $(3.26-3.32)$ & \\
\hline
\end{tabular}

greater difficulty in swimming, resulting in higher mortality, thus corroborating the length-frequency data.

\section{Discussion}

The observed maximum size for females was slightly larger than that found by Lucinda et al. (2005). The difference may be explained by the larger number of individuals analyzed, compared to the number of type specimens.

The larger weight increment as a function of length observed in females compared to males occurs because females invest more in growth than do males. This difference is common in poeciliids (Chapman, 1992; Machado et al., 2002) and is interpreted as a strategy to maximize reproductive output (Keane \& Neira, 2004) or influenced by a major weight of gonads in females (Wolff et al., 2007).

The number of embryos observed in the females analyzed was small compared to that in Phalloceros caudimaculatus, with 12.5 embryos found by Machado et al., (2002). This result can be explained by a larger proportional size of these embryos (28.4\% of female standard length) found for Phallotorynus pankalos. The smaller number may be a function of the larger size of embryos, which may result in a higher probability of survival of the embryos.

The positive correlation of sexual investment and female size is in agreement with many studies on fish reproductive biology and sexual investment. Larger females can allocate more energy to their offspring (Casatti et al., 2006; Mazzoni
\& Silva, 2006; Mai et al., 2007). However, the increase of embryo number with increase in female size reduces the survival probability of females; if the mean size of embryos is not reduced, then the large offspring of larger females may lead to death of the female.

Discussing population structure of Poecilia gillii, Chapman (1992) observed differences in sex ratios. In isolated pools, the sex ratios were approximately equal, whereas in streams the ratio was positively biased toward females, suggesting that differences in environmental characteristics and seasonally catastrophic mortality can affect the probability of survival, altering the sex ratio.

Despite the equal sex ratio at birth in poeciliid species, adult populations are positively biased toward females, because males suffer comparatively higher mortalities from predation, accelerated physiological aging, and stressors (Krumholz, 1948; Haynes \& Cashner, 1995). Gambusia holbrooki had more than 5 females per male in some samples in Tasmanian streams (Keane \& Neira, 2004). Bisazza et al., (2000) observed that males of Jenynsia multidentata (Anablepidae) couple with females furtively and without their consent, and expend a large part of the day in this activity; this may make the males less careful compared to females in avoiding predator attacks, biasing the sex ratio toward females.

In our study, we observed a low probability of survival in females after they reached the size at which $100 \%$ of females are reproductive. This result may be influenced by higher predation pressure after female reproduction, interacting with lower tolerance to infections. In the laboratory, many females died even without predators, resulting in a balanced sex ratio. The clear seasonality in sex ratio can be a result of decrease of reproductive investment in winter, in response to environmental unfavorable conditions, conducting to smaller female mortality rates and proportionally increasing their abundance when compared to males, however, only with the analysis of seasonality in reproductive intensity and female mortalities can explain this pattern.

Concluding, the smaller fecundity observed for P. pankalos, associated to its restrict geographic distribution and higher
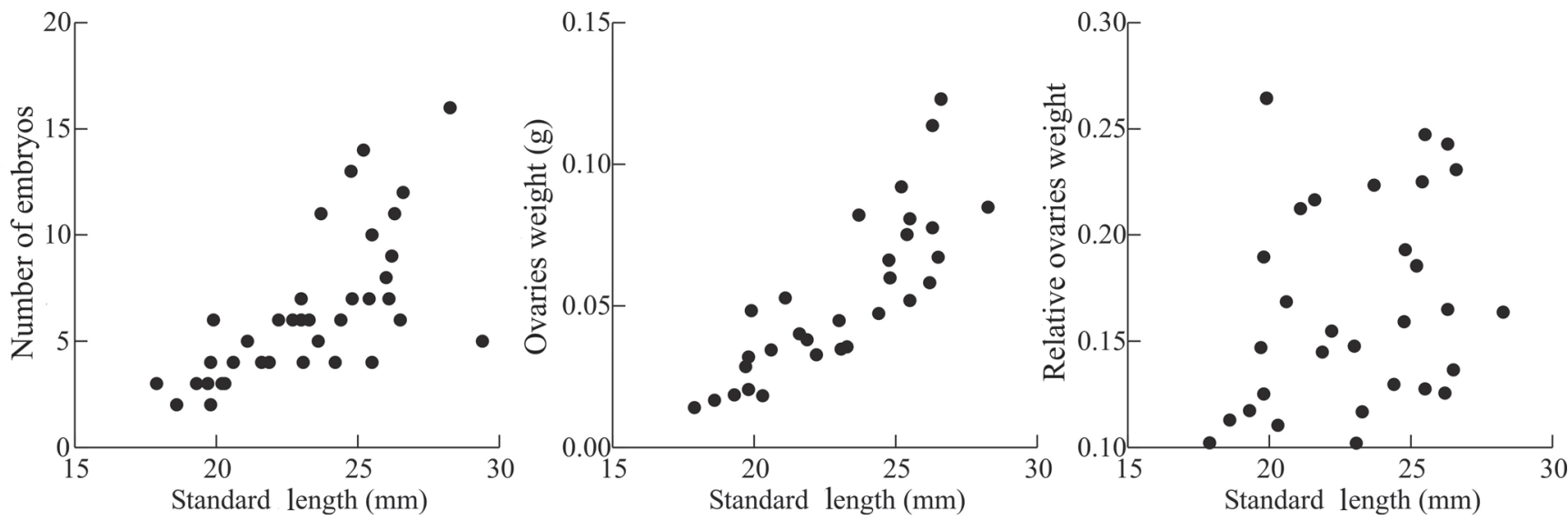

Fig. 4. Relationship between number of embryos, ovary weight and relative ovary weight and standard length (mm) for Phallotorynus pankalos in a first-order stream in the Iguatemi River Basin. 

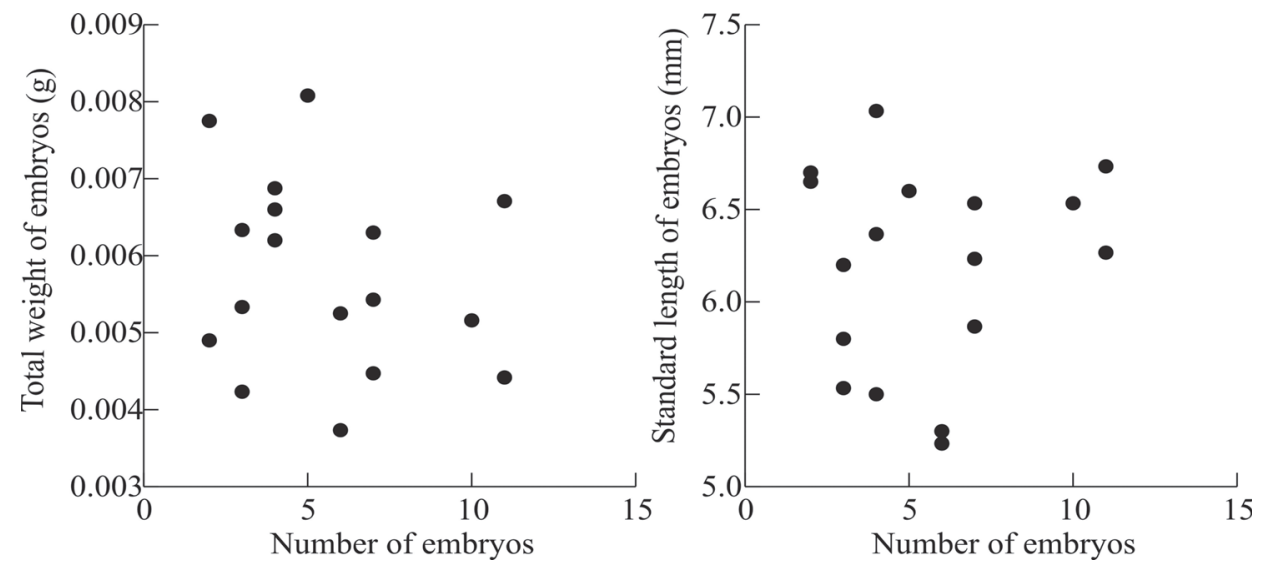

Fig. 5. Relationship between de number of embryos and mean total length and mean total weight of embryos of Phallotorynus pankalos in a first-order stream in the Iguatemi River Basin.

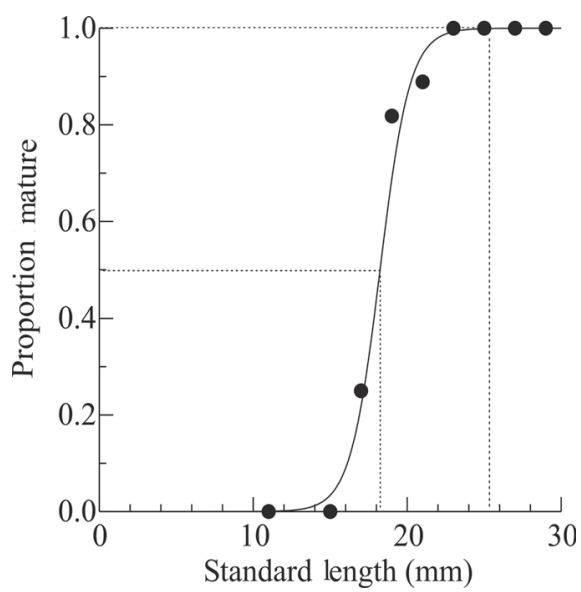

Fig. 6. Proportion of sexually mature females by standard length (mm) for Phallotorynus pankalos in a first-order stream in the Iguatemi River Basin. The black circles represent the observed proportion of mature females by $2 \mathrm{~mm}$ size class.

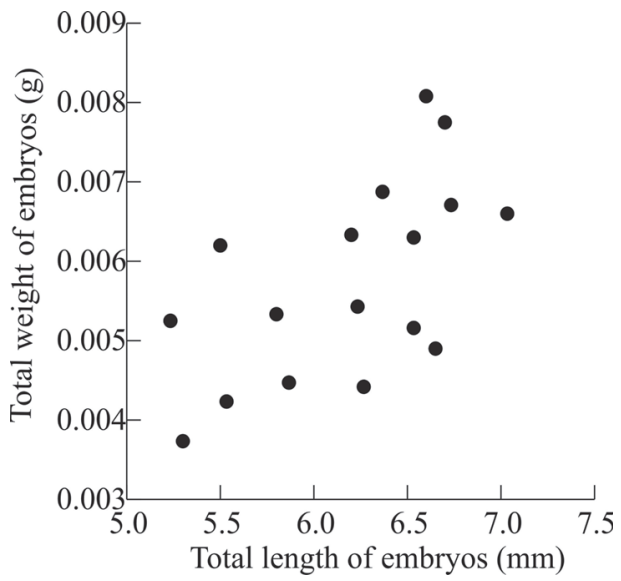

Fig. 7. Relationship between mean total weight and length of embryos of Phallotorynus pankalos in a first-order stream in the Iguatemi River Basin.
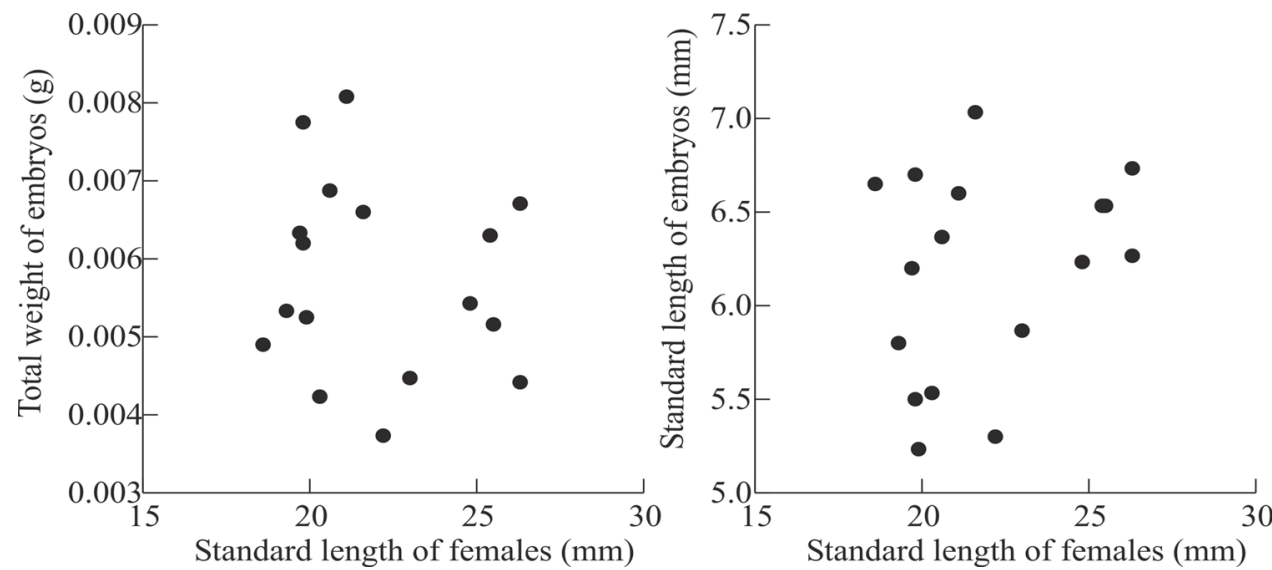

Fig. 8. Relationship between females standard length and mean embryos weight and length for Phallotorynus pankalos in a first-order stream in the Iguatemi River Basin. 


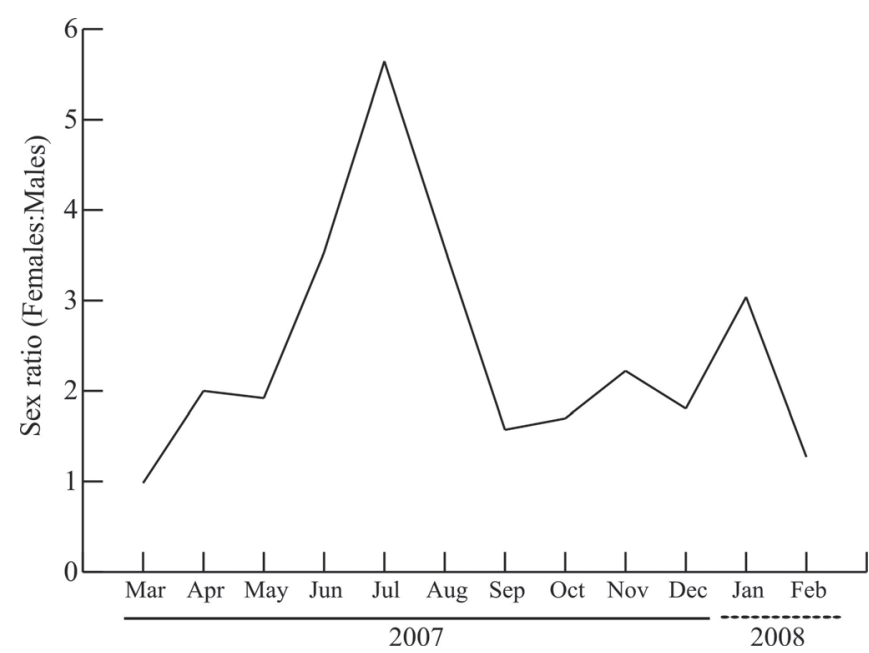

Fig. 9. Seasonal variation sex ratio (females: male) for Phallotorynus pankalos in a first-order stream in the Iguatemi River Basin from March/2007 to February/2008.

mortality rate for females after first reproduction can turn this species vulnerable to environmental degradation of its occurrence area (deforesting and siltation), reinforcing the need of other studies about its population ecology to propose policies for conservation of aquatic resources in this region.

\section{Acknowledgments}

To UEMS for financial support and Rodrigo Lingnau for his assistance in fieldwork. License for fish collection was granted by IBAMA (\#13458-1). To Jerry M. F. Penha (UFMT) for helpful comments and suggestions regarding this manuscript. Janet W. Reid revised the English text.

\section{Literature Cited}

Bisazza, A., S. Manfredi \& A. Pilastro. 2000. Sexual competition, coercive mating and mate assessment in the one-sided livebearer, Jenynsia multidentata: Are they predictive of sexual dimorphism? Ethology, 106: 961-978.

Bozzetti, M. \& U. H. Schulz. 2004. An index of biotic integrity based on fish assemblages for subtropical streams in southern Brazil. Hydrobiologia, 539: 133-144.

Casatti, L., F. R. Carvalho, J. L. Veronezi-Junior \& D. R. Lacerda. 2006. Reproductive biology of the Neotropical superfetaceous Pamphorichthys hollandi (Cyprinodontiformes: Poeciliidae). Ichthyological Exploration of Freshwaters, 17(1): 59-64.

Chapman, L. J. 1992. Variation in the structure of Poecilia gillii populations. Copeia, 1992(3): 908-914.

Cunico, A. M., A. A. Agostinho \& J. D. Latini. 2006. Influência da urbanização sobre as assembléias de peixes em três córregos de Maringá, Paraná. Revista Brasileira de Zoologia, 23(4): 1101-1110.

Endler, J. A. 1980. Natural selection on color patterns in Poecilia reticulata. Evolution, 34: 76-91.

Endler, J. A. 1983. Natural and sexual selection on color patterns in poeciliid fishes. Environmental Biology of Fishes, 9(2): 173-190.

Ferreira, C. P. \& L. Casatti. 2006. Integridade biótica de um córrego na bacia do Alto Rio Paraná avaliada por meio da comunidade de peixes. Biota Neotropica, 6: 1-25.
Gusmão, P. \& C. S. Pavanelli. 1996. Caracterização Morfológica de Machos e Fêmeas de Phalloceros caudimaculatus (Hensel, 1868), (Cyprinodontiformes: Poeciliidae). Revista Unimar, 18(2): 255-267.

Haynes, J. L. \& R. C. Cashner. 1995. Life history and population dynamics of the western mosquitofish: a comparison of natural and introduced populations. Journal of Fish Biology, 46: 1026-1041.

Keane, J. P. \& F. J. Neira. 2004. First record of mosquitofish, Gambusia holbrooki, in Tasmania, Australia: stock structure and reproductive biology. New Zealand Journal of Marine and Freshwater Research, 38: 857-867.

Krumholz, L. A. 1948. Reproduction in the western mosquitofish, Gambusia affinis, and its use in mosquito control. Ecological Monographs, 18: 1-43.

Langerhans, R. B., C. A. Layman, A. M. Shokrollahi \& T. J. Dewitt. 2004. Predator-driven phenotypic diversification in Gambusia affinis. Evolution, 58(10): 2305-2318.

Lucinda, P. H. F. 2003. Family Poeciliidae. Pp. 555-581. In: Reis, R.E., S.O. Kullander \& C. Ferraris Jr. (Eds.). Check List of the Freshwater Fishes of South and Central America. Porto Alegre, Edipucrs, 729p.

Lucinda, P. H. F. 2008. Systematics and Biogeography of the poecilid fishes genus Phalloceros with the descriptions of twenty-one new species. Neotropical Ichthyology, 6(2): 113-158.

Lucinda, P. H. F., R. S. Rosa \& R. E. Reis. 2005. Systematics and biogeography of the genus Phallotorynus Henn, 1916 (Cyprinodontiformes, Poeciliidae, Poeciliinae), with description of three new species. Copeia, 2005(3): 609-631.

Machado, G., A. A. Giaretta \& K. G. Facure. 2002. Reproductive cycle of a population of the guaru Phalloceros caudimaculatus (Poeciliidae) in Southeastern Brazil. Studies on Neotropical Fauna and Environment, 37: 15-18.

Magurran, A. E., B. H Seghers, P. W. Shaw \& G. R. Carvalho. 1995. The behavioral diversity and evolution of guppy, Poecilia reticulata, populations in Trinidad. Advances in the Study of Behavior, 24: 155-202.

Mai, A. C. G., A. M. Garcia, J. P.Vieira \& M. G. Mai. 2007. Reproductive aspects of one-sided livebearer Jenynsia multidentara (Jenyns, 1842) (Cyprinodontiformes) in the Patos Lagoon estuary, Brazil. Pan-American Journal of Aquatic Sciences, 2(1): 40-46.

Mazzoni, R. \& A. P. F. Silva. 2006. Aspectos da história de vida de Bryconamericus microcephalus (Miranda Ribeiro) (Characiformes, Characidae) de um riacho de Mata Atlântica, Ilha Grande, Rio de Janeiro, Brasil. Revista Brasileira de Zoologia, 23(1): 228-233.

Pinto, B. C. T., M. G. Peixoto \& F. G. Araújo. 2006. Effects of the proximity from an industrial plant on fish assemblages in the rio Paraíba do Sul, southeastern Brazil. Neotropical Ichthyology, 4(2): 269-278.

Roa, R., B. Ernst \& F. Tapia. 1999. Estimation of size at sexual maturity: an evaluation of analytical and resampling procedures. Fisheries Bulletin, 97: 570-580.

Vieira, D. B. \& O. A. Shibatta. 2007. Peixes como indicadores da qualidade ambiental do ribeirão Esperança, Município de Londrina, Paraná, Brasil. Biota Neotropica, 7(1): 1-9.

Wolf, L. L., E. R. Hreciuk, D. Viana, T. Zaleski \& L. Donatti. 2007. Population structure of Phalloceros caudimaculatus (Hensel, 1868) (Cyprinodontiformes, Poeciliidae) collected in a brook in Guarapuava, PR. Brazilian Archives of Biology and Technology, 50(3): 417-423.

Accepted January 2009

Published March 31, 2009 